\title{
Submandibular Gland/Sublingual Gland
}

National Cancer Institute

\section{Source}

National Cancer Institute. Submandibular Gland/Sublingual Gland. NCI Thesaurus. Code C92215.

A tissue sample that contains the submandibular and sublingual salivary glands. 